\title{
Characterization of Acylphosphatidylglycerols from Salmonella typhimurium by Tandem Mass Spectrometry with Electrospray Ionization
}

\author{
Fong-Fu Hsu and John Turk \\ Mass Spectrometry Resource, Division of Endocrinology, Diabetes, and Metabolism, Department of Internal \\ Medicine, Washington University School of Medicine, St. Louis, Missouri, USA \\ Yixin Shi and Eduardo A. Groisman \\ Department of Molecular Microbiology, Washington University School of Medicine, St. Louis, Missouri, USA
}

\begin{abstract}
Acylphosphatidylglycerol (Acyl-PG), a polar lipid class containing three fatty acyl groups, was isolated from Salmonella bacteria and characterized by tandem quadrupole and quadrupole ion-trap mass spectrometric methods with electrospray ionization. The structural characterization of the acyl-PG with various acyl groups (A-B/C-PG, where $A \neq B \neq C$ ) is based on the findings that the carboxylate anions $\left(\mathrm{R}_{x} \mathrm{CO}_{2}^{-}\right)$arising from $s n-2\left(\mathrm{R}_{2} \mathrm{CO}_{2}^{-}\right)$is more abundant than that arising from $s n-3^{\prime}\left(\mathrm{R}_{3}, \mathrm{CO}_{2}^{-}\right)$, which is much more abundant than that arising from $s n-1$ $\left(\mathrm{R}_{1} \mathrm{CO}_{2}^{-}\right)$. This information provides a simple method for determination of the fatty acyl moieties and their positions in the molecule. The structural identification of the molecule can also be achieved by the findings that the fragment ion reflecting the ketene loss at $s n-2$ is more prominent than that reflecting the acid loss (i.e., $\left[\mathrm{M}-\mathrm{H}-\mathrm{R}_{2}{ }_{2} \mathrm{CH}=\mathrm{CO}\right]^{-}>[\mathrm{M}-\mathrm{H}-$ $\left.\mathrm{R}_{2} \mathrm{CO}_{2} \mathrm{H}\right]^{-}$), while the ion arising from acid loss at $s n-1$ or $s n-3^{\prime}$ is, respectively, more abundant than the corresponding ketene loss (i.e., $\left[\mathrm{M}-\mathrm{H}-\mathrm{R}_{1} \mathrm{CO}_{2} \mathrm{H}\right]^{-}>\left[\mathrm{M}-\mathrm{H}-\mathrm{R}_{1}^{\prime} \mathrm{CH}=\mathrm{CO}\right]^{-}$; $[\mathrm{M}-$ $\left.\left.\mathrm{H}-\mathrm{R}_{3}, \mathrm{CO}_{2} \mathrm{H}\right]^{-}>\left[\mathrm{M}-\mathrm{H}-\mathrm{R}^{\prime}{ }^{\prime} \mathrm{CH}=\mathrm{CO}\right]^{-}\right)$. The identity of the acyl moiety at $s n-3^{\prime}$ can be confirmed by an acyl-glycerophosphate anion observed in the product-ion spectrum obtained with a triple-stage quadrupole (TSQ) instrument, but not in that obtained with an ion-trap mass spectrometer (ITMS). However, the $\mathrm{MS}^{2}$-spectrum obtained with an ITMS is featured by the ion series that abundances of $\left[\mathrm{M}-\mathrm{H}-\mathrm{R}_{2}{ }_{2} \mathrm{CH}=\mathrm{CO}-\mathrm{R}_{3} \mathrm{CO}_{2} \mathrm{H}-74\right]^{-}>\left[\mathrm{M}-\mathrm{H}-\mathrm{R}_{2}{ }_{2} \mathrm{CH}=\mathrm{CO}\right.$ $\left.-\mathrm{R}_{1} \mathrm{CO}_{2} \mathrm{H}-74\right]^{-} \gg\left[\mathrm{M}-\mathrm{H}-\mathrm{R}_{1\left(\text { or } 3^{\prime}\right)}^{\prime} \mathrm{CH}=\mathrm{CO}-\mathrm{R}_{3^{\prime}(\text { or } 1)} \mathrm{CO}_{2} \mathrm{H}-74\right]^{-}$. This information also facilitates structural elucidation of the acyl-PG subclass that contains various acyl substituents. Structural identifications of molecular species having two identical fatty acyl substituents at $s n-1, s n-2$, or $s n-3^{\prime}$ or consisting of more than one isomeric structures are also demonstrated. The identities of the minor isomeric species in the molecules can be revealed by the aforementioned structural information arising from the various ion series combined. (J Am Soc Mass Spectrom 2004, 15, 1-11) @ 2004 American Society for Mass Spectrometry
\end{abstract}

A cylphosphatidylglycerol (1,2-diacyl-sn-glycero3-phospho-(3'-acyl)-1'-sn-glycerol) (I) (AcylPG), a polar lipid containing three fatty acyl substituents, has been identified in mycoplasma [1], bacteria [2-5], mold [6], and trichomonads [7]. Small quantities of acyl-PG are also present in certain animal tissue [8-10] and cereals [11].

Structural determination of acyl-PG in oat oil was recently described by Holmback et al. [11], who used

Published online November 19, 2003

Address reprint requests to Dr. F. F. Hsu, Department of Internal Medicine, Washington University School of Medicine, 660 S. Euclid, Box 8127, St. Louis, MO 63110, USA. E-mail: fhsu@im.wustl.edu one- and two-dimensional ${ }^{1} \mathrm{H}$ - and ${ }^{13} \mathrm{C}-\mathrm{NMR}$, mass spectrometric methods including HPLC-tandem quadrupole mass spectrometry with electrospray ionization to analyze intact acyl-PG molecules, and GC/MS with electron impact ionization to analyze the fatty acid hydrolysates derivatized to picolinyl esters. Although the methods give information including the positions of the double bonds in the fatty acid substituents, structural details such as positions of the various fatty acyl substituents in the molecules consisting of multiple isomeric configurations were not available. Collisional-activated dissociation (CAD) tandem sector mass spectrometric methods with $\mathrm{FAB}$ were also used to identify acyl-PGs isolated from Corynebacterium spp. [12] and trichomonads [13]. 
However, a systematic approach towards the structural characterization of acyl-PGs using low-energy or highenergy CAD tandem mass spectrometry with electrospray ionization has not been described.

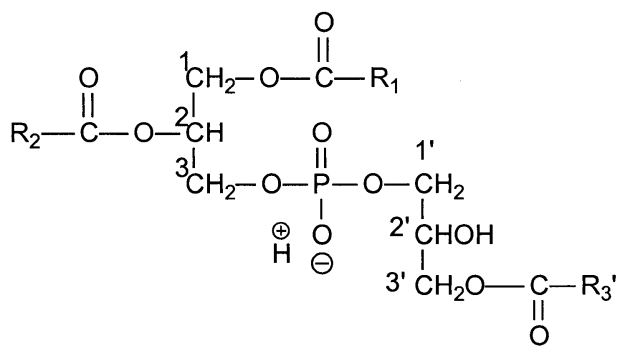

1,2-diacyl-sn-glycero-3-phospho-(3'-acyl)-1'-sn-glycerol (I)

We previously reported tandem mass spectrometric method in the determination of phosphatidylglycerol (PG). Structural information including the identities and the positions of the fatty acyl substituents in the glycerol backbone can be easily determined [14]. Herein, we present tandem mass spectrometric methods using both a triple quadrupole and a quadrupole ion-trap mass spectrometers to characterize acyl-PG. Structures of regio- and configuration isomers of acyl-PG molecules are revealed in details.

\section{Materials and Methods}

\section{Bacterial Strain and Medium}

Salmonella enterica serovar typhimurium strain used in this study is wild-type $14028 \mathrm{~s}$. N-minimal medium $\mathrm{pH}$ 7.4 supplemented with $0.1 \%$ casamino acids and $38 \mathrm{mM}$ glycerol, and $10 \mu \mathrm{M}$ or $10 \mathrm{mM}$ of $\mathrm{MgCl}_{2}$ were prepared as described [15].

\section{Isolation of Inner and Outer Membranes}

Bacteria were inoculated into $\mathrm{N}$ minimal medium at $\mathrm{pH}$ 7.4 containing $10 \mathrm{mM} \mathrm{MgCl}$ for overnight growth at 37 ${ }^{\circ} \mathrm{C}$ with aeration. The cultures were harvested and washed three times with the $\mathrm{N}$ minimal medium ( $\mathrm{pH} 7.4$, with $10 \mu \mathrm{M} \mathrm{MgCl}_{2}$ ). Cells were diluted to 1:100 with the same $\mathrm{N}$ minimal medium. Bacteria were incubated for $4 \mathrm{~h}$ at $37^{\circ} \mathrm{C}$ with aeration. Cells were harvested from $300 \mathrm{ml}$ culture and washed once with $50 \mathrm{ml}$ phosphate buffered saline (PBS). Pellet was suspended in $4 \mathrm{ml}$ of $10 \mathrm{mM}$ Tris- $\mathrm{HCl}$ (pH 8.0) containing 20\% sucrose, and sonicated for $5 \mathrm{~min}$. Cell debris was removed by centrifugation at $6500 \mathrm{rpm}$ for $10 \mathrm{~min}$ at $4{ }^{\circ} \mathrm{C}$. Inner and outer membranes were isolated by one step sucrose gradient procedure as previously described [16] (Hancock, http://www.cmdr. ubc.ca/bobh/methodsall.html). Briefly, the supernatant was loaded on a $60 \%$ and $70 \%$ sucrose discontinuous gradient centrifuge tube and spun at $38,000 \mathrm{rpm}$ at $4{ }^{\circ} \mathrm{C}$ for $18 \mathrm{~h}$. Upper reddish band near top of $60 \%$ sucrose that represents inner membrane portion and a band on the top of $70 \%$ sucrose containing outer membrane were collected and dialyzed against PBS (pH 7.4) for overnight with stirring. The membrane preparations were stored at $-80^{\circ} \mathrm{C}$.

\section{Extraction of Phospholipids from Membrane Preparations}

The procedure was as described [17]. To $1 \mathrm{ml}$ inner or outer membrane sample, $1.25 \mathrm{ml}$ chloroform and $2.5 \mathrm{ml}$ methanol were added. After vortexing for $2 \mathrm{~min}, 1.25$ $\mathrm{ml}$ chloroform was added, and vortexing continued for another $30 \mathrm{~s}$. This is followed by the addition of $1.25 \mathrm{ml}$ $\mathrm{H}_{2} \mathrm{O}$, and vortexing for another $30 \mathrm{~s}$. The mixture was centrifuged for $5 \mathrm{~min}$ at $3000 \mathrm{rpm}$. Lower phase containing phospholipids was collected for ESI/MS analysis.

\section{Mass Spectrometry}

Low-energy CAD tandem mass spectrometry experiments were conducted on a Finnigan (San Jose, CA) TSQ 7000 mass spectrometer equipped with ICIS data system or on a LCQ DECA ion-trap mass spectrometer with $\mathrm{X}$-caliber operation system. Extracts containing acyl-PG in methanol/chloroform solution (vol/vol, $1 / 1$ ) were continuously infused into the ESI source with a Harvard syringe pump at a flow rate of $1 u \mathrm{~L} / \mathrm{min}$. The skimmer was at ground potential and the electrospray needle was set at $4.5 \mathrm{kV}$. The temperature of the heated capillary was $260{ }^{\circ} \mathrm{C}$. For product-ion spectra obtained with a triple stage quadrupole (TSQ) instrument, the [M $-\mathrm{H}]^{-}$ions were selected in the first quadrupole (Q1), collided with Ar (2.3 mTorr) in the rf-only second quadrupole (Q2) using a collision energy of $34 \mathrm{eV}$ and analyzed in the third quadrupole (Q3). Both Q1 and Q3 were tuned to unit mass resolution and scanned at a rate of $3 \mathrm{~s} / \mathrm{scan}$. The mass spectra were accumulated in the profile mode, typically for 5-10 min for a tandem mass spectrum. For CAD tandem mass spectra obtained with a quadrupole ion-trap instrument, the automatic gain control of the ion trap was set to $5 \times 10^{7}$, with a maximum injection time of $400 \mathrm{~ms}$. Helium was used as the buffer and collision gas at a pressure of $1 \times 10^{-3}$ mbar. $\mathrm{MS}^{\mathrm{n}}$ experiments were carried out with a relative collision energy ranged from $30-35 \%$ and with an activation $q$ value, with which the mass range for the product-ion scan can be set from above the precursor ion mass to the lowest trapped mass that covers the $\mathrm{m} / \mathrm{z}$ value of the expected carboxylate anions. The activation time was set at $100 \mathrm{~ms}$. The mass resolution was $0.6 \mathrm{Da}$ at half peak height.

\section{Results and Discussion}

ESI Mass Spectrometry of the Acylphosphatidylglycerols Isolated from Salmonella typhimurium

When subjected to ESI in the negative-ion mode, the lipid extract yielded abundant $[\mathrm{M}-\mathrm{H}]^{-}$ions, that 

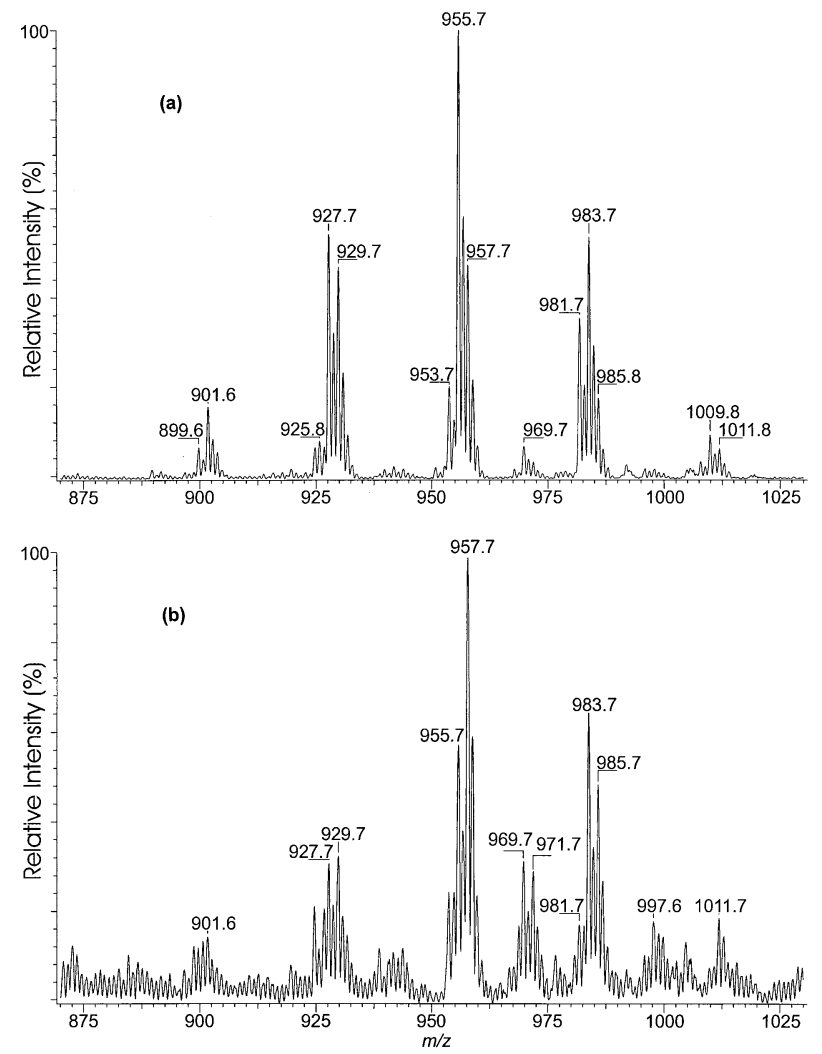

Figure 1. The negative-ion ESI mass spectra of acyl-PG extracts from (a) inner membrane, (b) outer membrane of Salmonella typhimurium.

could be attributed to acylphosphatidylglycerols (acylPG). However, in the positive-ion mode, ions reflecting the molecular species of acyl-PG were not observed. The ESI mass spectra of the acyl-PG acquired by a triple quadrupole instrument for the extracts isolated from inner (Figure 1a) and outer membranes (Figure 1b) of Salmonella typhimurium cells contain homologous [M $\mathrm{H}]^{-}$ions ranging from $\mathrm{m} / \mathrm{z} 889$ to 1011 , and are identical to that obtained by an ITMS (data not shown). More than one isomer was observed in most of the molecular species, as revealed by their tandem mass spectra (Table 1). The structural characterization of the molecules is described below.

\section{Characterization of Acylphosphatidylglycerols by CAD Tandem Quadrupole and $M S^{2}$-Ion-Trap Mass Spectrometry}

We previously reported tandem quadrupole mass spectrometric method in the characterization of phosphatidylglycerols (PG) [14]. The structural identification was based on the findings that: (1) Ions reflecting the losses of the fatty acyl substituent as an free acid ([M - H $\left.\left.\mathrm{R}_{2} \mathrm{CO}_{2} \mathrm{H}\right]^{-}\right)$and as a ketene $\left(\left[\mathrm{M}-\mathrm{H}-\mathrm{R}_{2}^{\prime} \mathrm{CH}=\mathrm{C}=\mathrm{O}\right]^{-}\right)$at $s n-2$ are respectively more abundant than the analogous losses at sn-1 (i.e., $\left[\mathrm{M}-\mathrm{H}-\mathrm{R}_{1} \mathrm{CO}_{2} \mathrm{H}\right]^{-}$and $[\mathrm{M}-\mathrm{H}$ $\mathrm{R}^{\prime}{ }_{1} \mathrm{CH}=\mathrm{C}=\mathrm{O}^{-}$ions). (2) The ion arising from a com-
Table 1. Acylphosphatidylglycerol compositions in Salmonella typhiurium determined by tandem mass spectrometry

\begin{tabular}{|c|c|c|c|c|c|}
\hline \multirow[b]{2}{*}[\mathrm{M}-\mathrm{H}]{$^{-2}$} & \multirow{2}{*}{$\frac{\begin{array}{c}\text { Inner } \\
\text { membrane }\end{array}}{\text { Relative In }}$} & \multirow{2}{*}{$\begin{array}{c}\begin{array}{c}\text { Outer } \\
\text { membrane }\end{array} \\
\text { tensity }(\%)\end{array}$} & \multicolumn{3}{|c|}{ Fatty acid } \\
\hline & & & $s n-1$ & $s n-2$ & $s n-3^{\prime}$ \\
\hline & & & $14: 0$ & $16: 1$ & $14: 1$ \\
\hline \multirow[t]{3}{*}{899} & 6 & $0^{3}$ & $16: 0^{*}$ & $16: 1$ & $12: 1$ \\
\hline & & & $18: 1^{*}$ & $14: 1$ & $12: 0$ \\
\hline & & & $16: 0$ & $16: 1$ & $12: 0$ \\
\hline \multirow[t]{2}{*}{901} & 15 & 14 & $16: 0$ & $14: 0$ & $14: 1$ \\
\hline & & & $12: 0$ & 18:1 & $14: 0$ \\
\hline 925 & 7 & $0^{3}$ & $16: 1$ & $16: 1$ & $14: 1$ \\
\hline \multirow[t]{2}{*}{927} & 54 & 30 & 16:0 & $16: 1$ & $14: 1$ \\
\hline & & & 18:1 & $16: 1$ & $12: 0$ \\
\hline \multirow[t]{2}{*}{929} & 47 & 32 & $16: 0$ & $16: 1$ & $14: 0$ \\
\hline & & & $16: 0$ & $18: 1$ & $12: 0$ \\
\hline \multirow[t]{3}{*}{953} & 20 & 24 & $16: 1$ & $16: 1$ & $16: 1$ \\
\hline & & & $18: 1$ & $16: 1$ & $14: 1$ \\
\hline & & & $16: 0$ & $16: 1$ & $16: 1$ \\
\hline \multirow[t]{2}{*}{955} & 100 & 58 & $16: 0$ & $18: 1$ & $14: 1$ \\
\hline & & & $16: 1$ & $18: 1$ & $14: 0$ \\
\hline \multirow[t]{2}{*}{957} & 45 & 100 & $16: 0$ & $16: 1$ & $16: 0$ \\
\hline & & & $16: 0$ & $18: 1$ & $14: 0$ \\
\hline \multirow[t]{2}{*}{$969^{1}$} & 6 & 32 & $16: 0$ & $17: 1$ & $16: 1$ \\
\hline & & & $16: 0$ & $17: 1$ & $16: 0$ \\
\hline \multirow[t]{2}{*}{971} & $0^{3}$ & 30 & $16: 0$ & $18: 1$ & $15: 0$ \\
\hline & & & $16: 0$ & $16: 1$ & $17: 0$ \\
\hline \multirow[t]{2}{*}{981} & 35 & 18 & $18: 1$ & $16: 1$ & $16: 1$ \\
\hline & & & $16: 1$ & $18: 1$ & $14: 1$ \\
\hline \multirow[t]{2}{*}{983} & 53 & $0^{3}$ & $16: 0$ & $18: 1$ & $16: 1$ \\
\hline & & & 18:1 & 16:1 & $16: 0$ \\
\hline \multirow[t]{2}{*}{$983^{2}$} & $0^{3}$ & 65 & $18: 1$ & $16: 1$ & $16: 0$ \\
\hline & & & $16: 1$ & 18:1 & $16: 0$ \\
\hline 985 & 17 & 48 & $16: 0$ & $18: 1$ & $16: 0$ \\
\hline \multirow[t]{2}{*}{997} & $0^{3}$ & 18 & $18: 1$ & $17: 1$ & $16: 0$ \\
\hline & & & $17: 0$ & 18:1 & $16: 1$ \\
\hline \multirow[t]{2}{*}{999} & $0^{3}$ & 15 & $16: 0$ & 19:1 & $16: 0$ \\
\hline & & & $17: 0$ & $18: 1$ & $16: 0$ \\
\hline 1009 & 10 & $0^{3}$ & $18: 1$ & $18: 1$ & $16: 1$ \\
\hline 1011 & 7 & 18 & $18: 1$ & $18: 1$ & $16: 0$ \\
\hline
\end{tabular}

* Structure not conclusive.

${ }^{1}$ Structure not conclusive, minor species contains 14:1-, 14:0-, 15:0-, 18:1-, 19:1-fatty acyl

${ }^{2}$ Species observed in the outer membrane

${ }^{3}$ Abundance close to background

bined losses of the $s n-2$ fatty acid substituent and polar head group ([M - $\left.\left.\mathrm{H}-\mathrm{R}_{2} \mathrm{CO}_{2} \mathrm{H}-74\right]^{-}\right)$is more abundant than the ion arising from the corresponding losses at sn-1 ([M - $\left.\left.\mathrm{H}-\mathrm{R}_{1} \mathrm{CO}_{2} \mathrm{H}-74\right]^{-}\right)$. (3) The $[\mathrm{M}-\mathrm{H}$ $\left.\mathrm{R}_{2}^{\prime} \mathrm{CH}=\mathrm{C}=\mathrm{O}\right]^{-}$ion is more abundant than the $[\mathrm{M}-\mathrm{H}$ $\left.\mathrm{R}_{2} \mathrm{CO}_{2} \mathrm{H}\right]^{-}$ion, whereas the $\left[\mathrm{M}-\mathrm{H}-\mathrm{R}_{1} \mathrm{CO}_{2} \mathrm{H}\right]^{-}$ion is more abundant than the $\left[\mathrm{M}-\mathrm{H}-\mathrm{R}^{\prime}{ }_{1} \mathrm{CH}=\mathrm{C}=\mathrm{O}\right]^{-}$ion. (4) The carboxylate anion arising from $s n-2\left(\mathrm{R}_{2} \mathrm{CO}_{2}^{-}\right)$is more abundant than that arising from $s n-1\left(\mathrm{R}_{1} \mathrm{CO}_{2}^{-}\right)$. As shown in Figure 2, the product-ion spectrum of the $[\mathrm{M}$ $-\mathrm{H}]^{-}$ion of 16:0/16:1-PG standard at $m / z 719$ (Panel a) is dominated by the caboxylate anions at $\mathrm{m} / \mathrm{z} 253$ $\left(\mathrm{R}_{2} \mathrm{CO}_{2}^{-}\right)$and $255\left(\mathrm{R}_{1} \mathrm{CO}_{2}^{-}\right)$, and the former ion is more abundant than the latter. The $\mathrm{m} / \mathrm{z} 483$ ([M - H $\left.\left.\mathrm{R}_{2}{ }_{2} \mathrm{CH}=\mathrm{C}=\mathrm{O}\right]^{-}\right)$and $m / z 465\left(\left[\mathrm{M}-\mathrm{H}-\mathrm{R}_{2} \mathrm{CO}_{2} \mathrm{H}\right]^{-}\right)$ions are respectively more abundant than $\mathrm{m} / z 481$ ([M - H - 


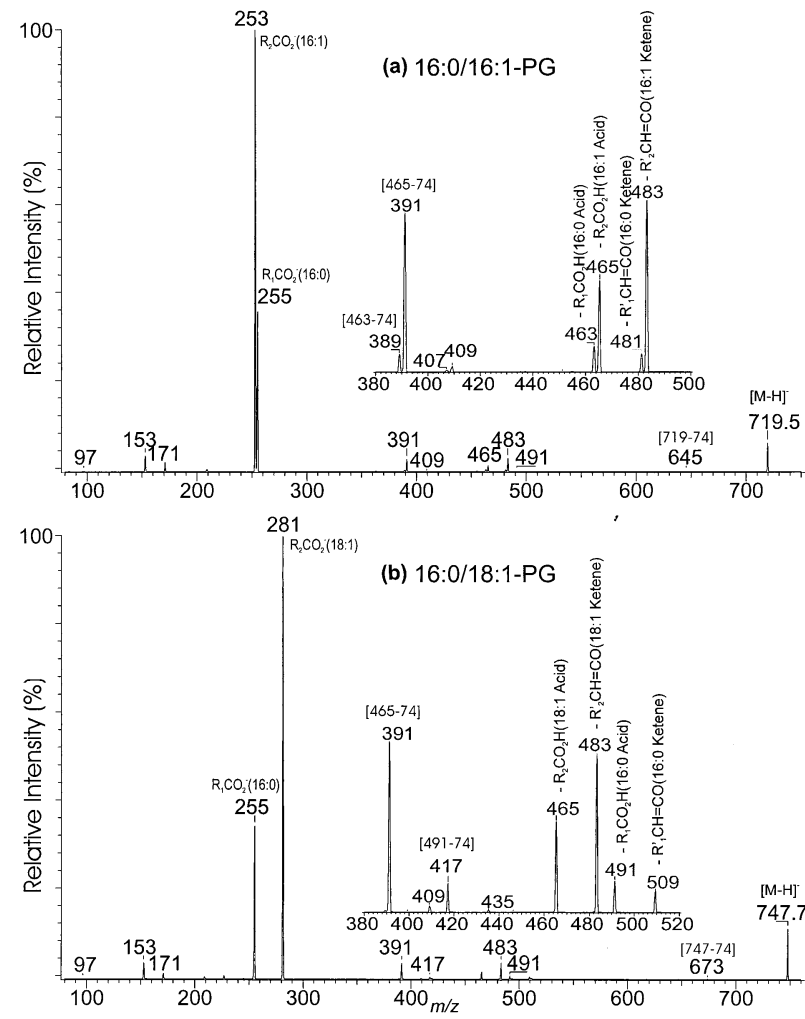

Figure 2. The tandem quadrupole ESI product-ion spectra of the $[\mathrm{M}-\mathrm{H}]^{-}$ions of (a) 16:0/16:1-PG at $m / z$ 719, and (b) 16:0/18:1-PG at $m / z 747$.

$\left.\left.\mathrm{R}^{\prime}{ }_{1} \mathrm{CH}=\mathrm{C}=\mathrm{O}\right]^{-}\right)$and $463\left(\left[\mathrm{M}-\mathrm{H}-\mathrm{R}_{1} \mathrm{CO}_{2} \mathrm{H}\right]^{-}\right)$. The $\mathrm{m} / \mathrm{z}$ $483\left(\left[\mathrm{M}-\mathrm{H}-\mathrm{R}_{2}{ }_{2} \mathrm{CH}=\mathrm{C}=\mathrm{O}\right]^{-}\right)$ion is more abundant than $m / z 465$ ([M- $\left.\left.\mathrm{H}-\mathrm{R}_{2} \mathrm{CO}_{2} \mathrm{H}\right]^{-}\right)$, whereas the $m / z 481$ ( $\left[\mathrm{M}-\mathrm{H}-\mathrm{R}^{\prime}{ }_{1} \mathrm{CH}=\mathrm{C}=\mathrm{O}\right]^{-}$) is slightly less abundant than $\mathrm{m} / z 463\left(\left[\mathrm{M}-\mathrm{H}-\mathrm{R}_{1} \mathrm{CO}_{2} \mathrm{H}\right]^{-}\right)$. The spectrum is also featured by the much greater abundance of the $\mathrm{m} / \mathrm{z} 391$ ion ([M - $\left.\left.\mathrm{H}-\mathrm{R}_{2} \mathrm{CO}_{2} \mathrm{H}-74\right]^{-}\right)(465-74)$ than $\mathrm{m} / z 389$ ([M $\left.\left.-\mathrm{H}-\mathrm{R}_{1} \mathrm{CO}_{2} \mathrm{H}-74\right]\right)$ (463 - 74). These spectrum features were also observed in the product-ion spectrum of 16:0/18:1-PG standard at $m / z 747$ (Panel b) [14].

When subjected to low-energy CAD, the $[\mathrm{M}-\mathrm{H}]^{-}$ ions of acyl-PG yielded major ion series similar to those observed for PG. The product-ion spectrum contains the ion series that correspond to neutral loss of free fatty acid $\left(\left[\mathrm{M}-\mathrm{H}-\mathrm{R}_{\mathrm{x}} \mathrm{CO}_{2} \mathrm{H}\right]^{-}\right)$, neutral loss of ketene ([M $\mathrm{H}-\mathrm{R}_{\mathrm{x}}{ }_{\mathrm{CH}} \mathrm{CH}=\mathrm{C}=\mathrm{O}^{-}$), along with the fatty carboxylate anions $\left(\left[\mathrm{R}_{\mathrm{x}} \mathrm{CO}_{2}\right]^{-}\right)$. The spectrum also contains the ion series that arises from further losses of the fatty acid moiety at $s n-1$ (or $\left.s n-3^{\prime}\right)$ and a dehydrated glycerol from $\left[\mathrm{M}-\mathrm{H}-\mathrm{R}_{2}{ }_{2} \mathrm{CH}=\mathrm{C}=\mathrm{O}\right]^{-}\left(\left[\mathrm{M}-\mathrm{H}-\mathrm{R}_{2}{ }_{2} \mathrm{CH}=\mathrm{C}=\mathrm{O}-\right.\right.$ $\left.\mathrm{R}_{\mathrm{x}} \mathrm{CO}_{2} \mathrm{H}-74\right]^{-}$, where $\mathrm{x}=1$ or $3^{\prime}$ ).

The $\left[\mathrm{M}-\mathrm{H}-\mathrm{R}_{x} \mathrm{CO}_{2} \mathrm{H}\right]^{-}$and $[\mathrm{M}-\mathrm{H}-$ $\mathrm{R}^{\prime}{ }_{x} \mathrm{CH}=\mathrm{C}=\mathrm{Ol}^{-}$Ions

As shown in Figure 3, the product-ion spectrum of the $[\mathrm{M}-\mathrm{H}]^{-}$ion at $\mathrm{m} / \mathrm{z} 927$ (Panel a) obtained with a TSQMS is dominated by the carboxylate anions at $\mathrm{m} / \mathrm{z}$

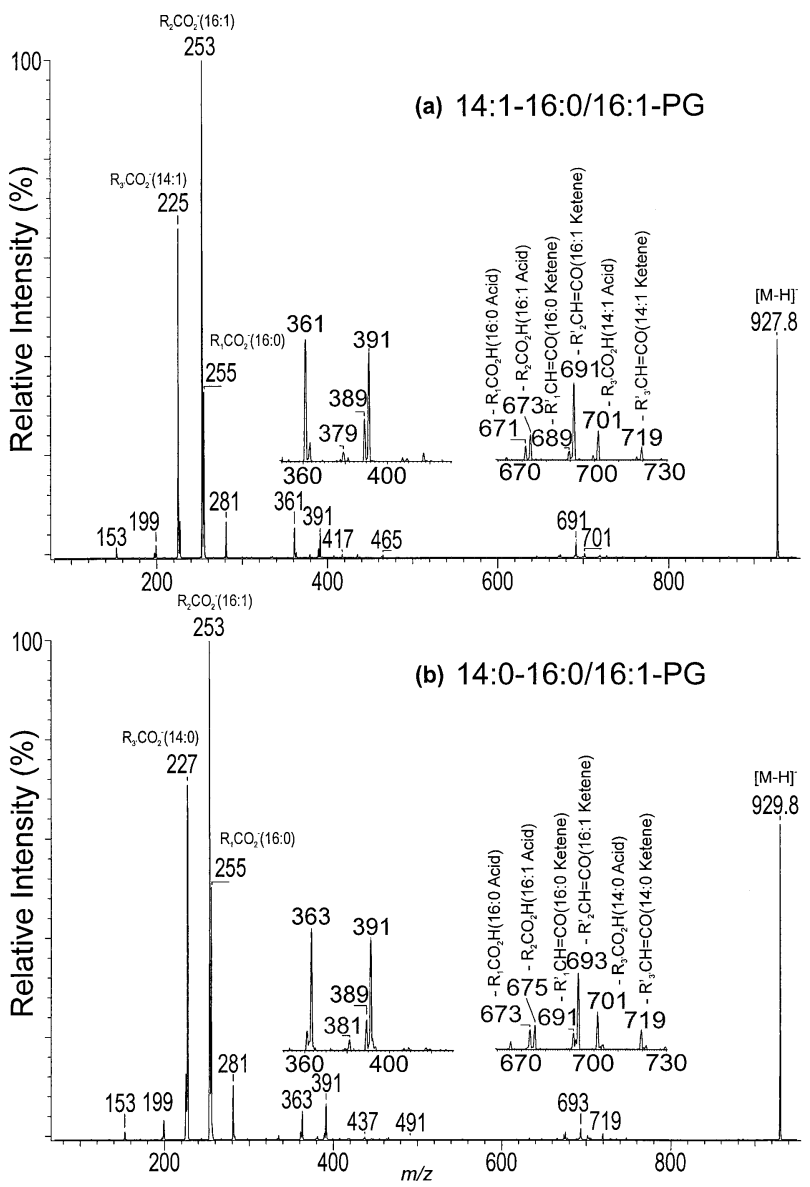

Figure 3. The tandem quadrupole ESI product-ion spectra of the $[\mathrm{M}-\mathrm{H}]^{-}$ions of (a) 14:1-16:0/16:1-PG at $\mathrm{m} / \mathrm{z}$ 927, (b) 14:0-16:0/ 16:1-PG at $m / z 929$.

$255 \quad\left(\mathrm{C}_{15} \mathrm{H}_{31} \mathrm{CO}_{2}^{-}\right), \quad 253 \quad\left(\mathrm{C}_{15} \mathrm{H}_{29} \mathrm{CO}_{2}^{-}\right)$and 225 $\left(\mathrm{C}_{13} \mathrm{H}_{27} \mathrm{CO}_{2}^{-}\right)$, reflecting the palmitoyl (16:0), palmitoleoyl (16:1), and myristoleoyl (14:1) substituents of the molecule, respectively. This is consistent with the observation of the ions at $\mathrm{m} / z 701$ ([M - H $\left.\left.\mathrm{C}_{13} \mathrm{H}_{25} \mathrm{CO}_{2} \mathrm{H}\right]^{-}\right), 673\left(\left[\mathrm{M}-\mathrm{H}-\mathrm{C}_{15} \mathrm{H}_{29} \mathrm{CO}_{2} \mathrm{H}\right]^{-}\right)$and 671 $\left(\left[\mathrm{M}-\mathrm{H}-\mathrm{C}_{15} \mathrm{H}_{31} \mathrm{CO}_{2} \mathrm{H}\right]^{-}\right)$, arising from losses of the 14:1, 16:1 and 16:0- fatty acid, respectively. The fatty acyl substituents are also reflected by the fragment ions at $m / z 719\left(\left[\mathrm{M}-\mathrm{H}-\mathrm{C}_{12} \mathrm{H}_{23} \mathrm{CHC}=\mathrm{O}\right]^{-}\right), 691([\mathrm{M}-\mathrm{H}-$ $\left.\left.\mathrm{C}_{14} \mathrm{H}_{29} \mathrm{CHC}=\mathrm{O}\right]^{-}\right)$and $689\left(\left[\mathrm{M}-\mathrm{H}-\mathrm{C}_{14} \mathrm{H}_{31} \mathrm{CHC}=\mathrm{O}^{-}\right)\right.$, arising from the losses of the 14:1,16:1, and 16:0-fatty acyl ketene from $m / z 927$, respectively. The $m / z 691$ ion is more abundant than the $\mathrm{m} / \mathrm{z} 673$ ion, and the ion pairs are the most prominent among the ion series (Panel a, subset). In contrast, the abundances of the $m / z 701$ and $\mathrm{m} / z 671$ ions are respectively greater than those of the $\mathrm{m} / \mathrm{z} 719$ and $\mathrm{m} / \mathrm{z} 689$ ions. The preferential loss of 16:1-ketene to the $m / z 691$ ion over the loss of 16:1-acid to $m / z 673$ ion, indicates that the 16:1-fatty acyl substituent probably resides at $s n-2$ of the glycerol backbone, whereas the 16:0-fatty acyl group resides at $s n-1$, similar to that observed for PG (Figure 2). The remaining 14:1-fatty acyl substituent is attached to the $3^{\prime}$ position 
(a)

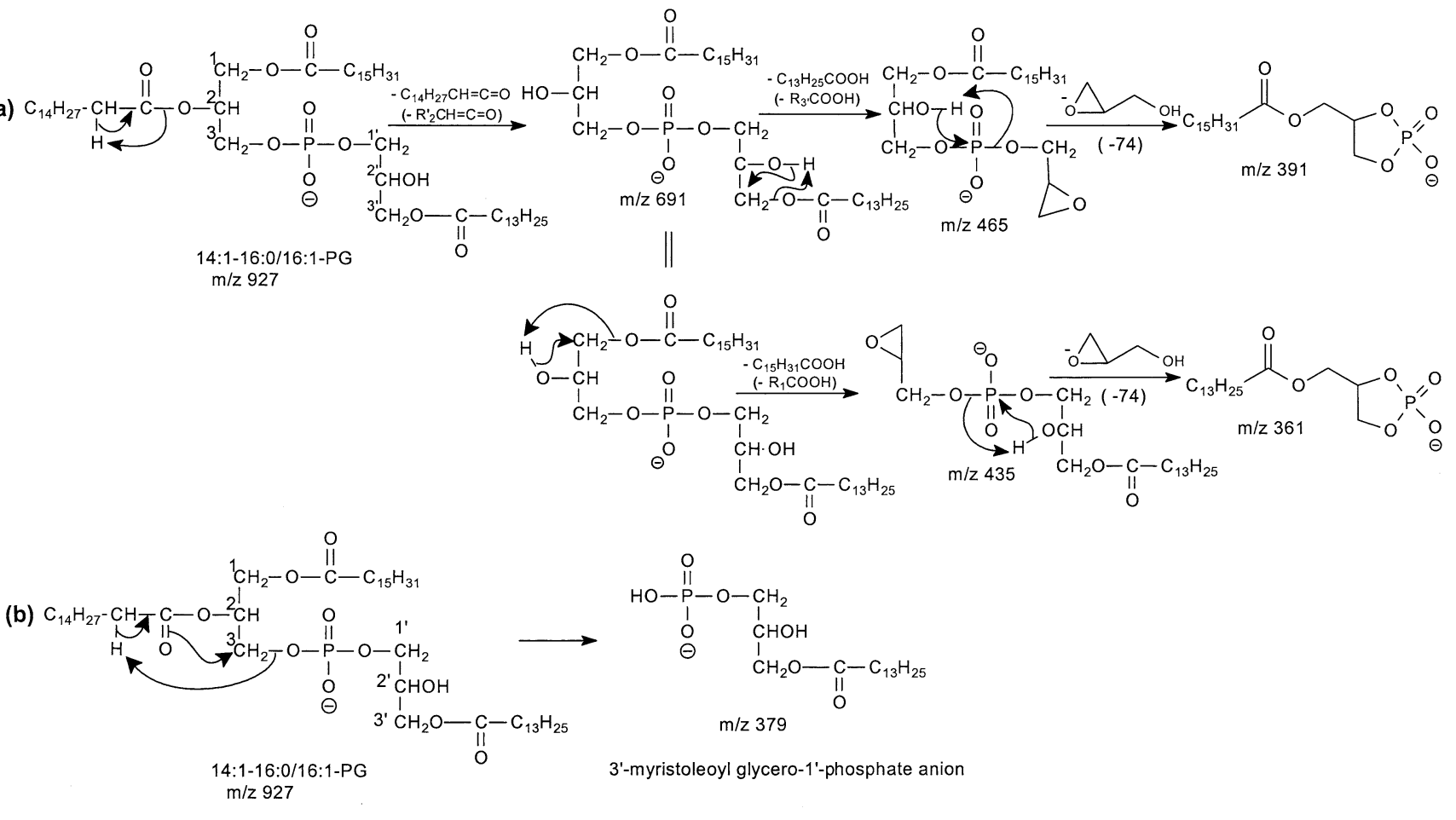

Scheme 1

of the glycerol head group. This speculation is based on the findings that ions at $m / z 719$ and 701 arising from a 14:1- ketene and acid losses, respectively, are more abundant than the ions at $m / z 689$ and 671, arising from the analogous losses from a 16:0 fatty acid. The production spectrum of the $[\mathrm{M}-\mathrm{H}]^{-}$ion at $m / z 929$ (Panel b) contains a similar ion profile that reflects the presence of a 14:0-, 16:0-, and 16:1-fatty acyl moieties and represents a 14:0-16:0/16:1-PG structure. The identities of the fatty acyl moieties and their positions in the glycerol backbone or in the glycerol head group were further confirmed by the $\left[\mathrm{M}-\mathrm{H}-\mathrm{R}_{2}{ }_{2} \mathrm{CH}=\mathrm{C}=\mathrm{O}-\mathrm{R}_{\mathrm{x}} \mathrm{CO}_{2} \mathrm{H}-74\right]^{-}$ and $\mathrm{R}_{\mathrm{x}} \mathrm{CO}_{2}^{-}$ion series, and by the $\mathrm{MS}^{2}$ and $\mathrm{MS}^{3}$ production spectra obtained with an ITMS as described later.

\section{The $\left[\mathrm{M}-\mathrm{H}-\mathrm{R}_{2}{ }_{2} \mathrm{CH}=\mathrm{C}=\mathrm{O}-\mathrm{R}_{x} \mathrm{CO}_{2} \mathrm{H}-74\right]^{-}$Ions}

In addition to the above ions readily available for structural assignment, the product-ion spectrum of $\mathrm{m} / \mathrm{z}$ 927 (Figure 3a) contains ions at $m / z 391$ ([M - H $\left.\mathrm{R}_{2}{ }_{2} \mathrm{CH}=\mathrm{C}=\mathrm{O}-74-\mathrm{R}_{3}, \mathrm{CO}_{2} \mathrm{H}\right]^{-}$) and $361([\mathrm{M}-\mathrm{H}-$ $\left.\mathrm{R}_{2}^{\prime} \mathrm{CH}=\mathrm{C}=\mathrm{O}-74-\mathrm{R}_{1} \mathrm{CO}_{2} \mathrm{H}\right]^{-}$), probably arising from an initial loss of the 16:1-fatty acyl substituent at $s n-2$ as a ketene to $m / z 691$, which dissociates to $m / z 465$ and 435 by losses of the fatty acid substituents at $s n-3^{\prime}$ and $s n-1$, respectively. This is followed by an additional loss of a dehydrated glycerol (74 Da) to yield ions at $\mathrm{m} / \mathrm{z} 391$ and 361 , respectively. This fragmentation process results in probably a five-member ring ion, comprising a 16:0- or 14:1-acyl moiety, respectively (Scheme 1a). The above fragmentation pathways are further supported by the $\mathrm{MS}^{3}$-product-ion spectrum of $\mathrm{m} / \mathrm{z} 691$ (Figure $5 \mathrm{c}$ ). In contrast, the $m / z 389$ ion, comprising a 16:1 fatty acyl that resides at $s n-2$ of the glycerol backbone is of low-abundance, similar to that observed for 16:0/16: 1-PG (Figure 2a) [14]. A unique ion at $m / z 379$, corresponding to a 3'-myristoleoyl glycerophosphate anion (Scheme 1b) is also observed. An analogous ion at $\mathrm{m} / \mathrm{z}$ 381 is also present in the product-ion spectrum of 14:0-16:0/16:1-PG at $m / z 929$ (Panel $b$ ). The results are consistent with the notion that a 14:1- and 14:0-fatty acyl moieties are respectively positioned at the $s n-3^{\prime}$ of the glycerol head group of the two molecules.

\section{The Carboxylate Anions $\left(\mathrm{R}_{x} \mathrm{CO}_{2}^{-}\right)$}

Both the $[\mathrm{M}-\mathrm{H}]^{-}$ions of PG and acyl-PG share a structure, in which the anionic charge site probably resides at the phosphate. As previously described by us $[14,18,19]$, the preferential formation of the $\mathrm{R}_{2} \mathrm{CO}_{2}^{-}$ion over the $\mathrm{R}_{1} \mathrm{CO}_{2}^{-}$ion for $\mathrm{PG}$ is due to the fact that nucleophilic attack by the anionic phosphate charge site on the C-2 of the glycerol backbone to yield a $\mathrm{R}_{2} \mathrm{CO}_{2}^{-}$ ion is sterically more favorable than that on $\mathrm{C}-1$ that results in $\mathrm{R}_{1} \mathrm{CO}_{2}^{-}$. This is consistent with the notion that the $m / z 253$ ion arising from a 16:1-fatty acyl at $s n-2$ is the most prominent in the spectrum of $m / z 927$ (Figure $3 a)$, whereas the less prominent carboxylate anions at $\mathrm{m} / \mathrm{z} 255$ and 225, arising from a 16:0- and 14:1-fatty acid moieties, respectively, are likely located at $s n-1$ and $s n-3^{\prime}$, respectively. This assumption is also based on the findings that the abundance ratios of the $m / z 255$ ion to $m / z 253$ observed for $m / z 927$ (Figure 3a) is similar to that observed for the 16:0/16:1-PG standard (Figure 2a). 
Full ms²927.70@34.00 [ 210.00-960.00]
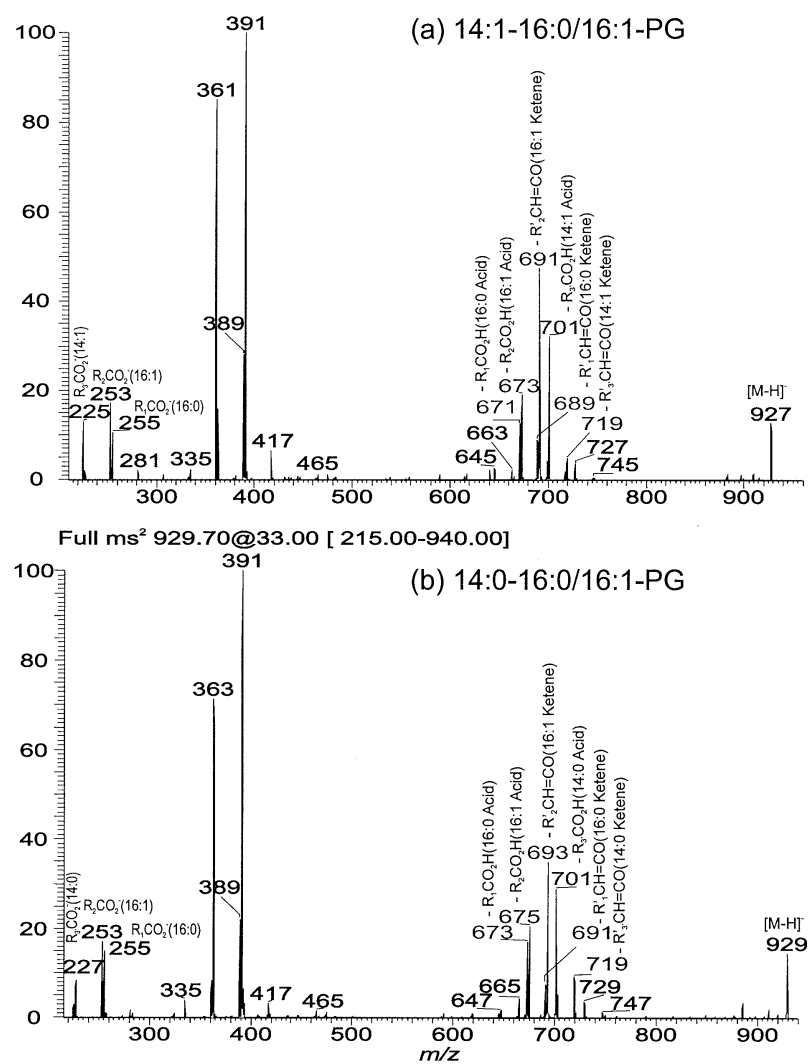

Figure 4. The ESI ITMS MS ${ }^{2}$ spectra of the $[\mathrm{M}-\mathrm{H}]^{-}$ions of (a) 14:1-16:0/16:1-PG at $m / z$ 927, and (b) 14:0-16:0/16:1-PG at $m / z$ 929 .

The observation of the abundances of: $\mathrm{R}_{2} \mathrm{CO}_{2}^{-}>$ $\mathrm{R}_{3}, \mathrm{CO}_{2}^{-}>\mathrm{R}_{1} \mathrm{CO}_{2}^{-}$in the product-ion spectrum of acyl-PG provides the simplest method to locate and identify the fatty acyl moieties of the molecule.

\section{Characterization of Acylphosphatidylglycerols by the $M S^{2}$ Spectrum Obtained with ITMS}

The MS ${ }^{2}$ spectrum of an acyl-PG obtained with an ITMS contains fragment ions similar to those obtained with a TSQ and is readily applicable for structural characterization. However, the spectrum is dominated by $[\mathrm{M}-$ $\left.\mathrm{H}-\mathrm{R}_{\mathrm{x}} \mathrm{CO}_{2} \mathrm{H}\right]^{-},\left[\mathrm{M}-\mathrm{H}-\mathrm{R}_{\mathrm{x}} \mathrm{CHC}=\mathrm{O}^{-},[\mathrm{M}-\mathrm{H}-\right.$ $\left.\mathrm{R}_{2}^{\prime} \mathrm{CH}=\mathrm{C}=\mathrm{O}-74-\mathrm{R}_{3^{\prime}} \mathrm{CO}_{2} \mathrm{H}\right]^{-}$and $\left[\mathrm{M}-\mathrm{H}-\mathrm{R}_{2}{ }_{2} \mathrm{CH}=\mathrm{C}=\mathrm{O}\right.$ - $\left.74-\mathrm{R}_{1} \mathrm{CO}_{2} \mathrm{H}\right]^{-}$series ions, and the $\mathrm{R}_{\mathrm{x}} \mathrm{CO}_{2}^{-}$ions are of low abundance. As shown in Figure 4, the structural characterization of the 14:1-16:0/16:1-PG at $\mathrm{m} / \mathrm{z} 927$ (Panel a) can be easily achieved by the findings that the ion prominence follows the pattern: $\mathrm{m} / z 691([\mathrm{M}-\mathrm{H}$ $\left.\left.\mathrm{C}_{14} \mathrm{H}_{27} \mathrm{CH}=\mathrm{CO}\right]^{-}\right)>673\left(\left[\mathrm{M}-\mathrm{H}-\mathrm{C}_{15} \mathrm{H}_{29} \mathrm{CO}_{2} \mathrm{H}\right]^{-}\right) ; 719$ $\left(\left[\mathrm{M}-\mathrm{H}-\mathrm{C}_{12} \mathrm{H}_{23} \mathrm{CH}=\mathrm{CO}\right]^{-}\right)<701([\mathrm{M}-\mathrm{H}-$ $\left.\left.\mathrm{C}_{13} \mathrm{H}_{25} \mathrm{CO}_{2} \mathrm{H}\right]^{-}\right) ; m / z 689\left(\left[\mathrm{M}-\mathrm{H}-\mathrm{C}_{14} \mathrm{H}_{29} \mathrm{CH}=\mathrm{CO}\right]^{-}\right)<$ $\mathrm{m} / \mathrm{z} 671\left(\left[\mathrm{M}-\mathrm{H}-\mathrm{C}_{15} \mathrm{H}_{31} \mathrm{CO}_{2} \mathrm{H}\right]^{-}\right)$. The $\mathrm{m} / \mathrm{z} 253\left(\mathrm{R}_{2} \mathrm{CO}_{2}^{-}\right)$ is more abundant than $m / z 225\left(\mathrm{R}_{3}, \mathrm{CO}_{2}^{-}\right)$, which is more abundant than $\mathrm{m} / \mathrm{z} 255\left(\mathrm{R}_{1} \mathrm{CO}_{2}^{-}\right)$, consistent with that observed with a TSQ and readily for structural determination. Similar results were also observed for the $[\mathrm{M}$ $-\mathrm{H}]^{-}$ion of 14:0-16:0/16:1-PG at $\mathrm{m} / z 929$ (Panel b).
One of the most interesting feature in the spectrum is that the $\mathrm{m} / \mathrm{z} 391$ ion $\left(\left[\mathrm{M}-\mathrm{H}-\mathrm{R}_{2}{ }_{2} \mathrm{CH}=\mathrm{CO}-74-\right.\right.$ $\left.\mathrm{R}_{3}, \mathrm{CO}_{2} \mathrm{H}\right]^{-}$) appears to be the most prominent and is slightly more abundant than $\mathrm{m} / \mathrm{z} 361$ ([M $-\mathrm{H}-\mathrm{R}_{2 \text { (or }}$ 1) $\left.\mathrm{CH}=\mathrm{CO}-74-\mathrm{R}_{1(\text { or } 2)} \mathrm{CO}_{2} \mathrm{H}\right]^{-}$), which is much more abundant than $\mathrm{m} / \mathrm{z} 389\left(\left[\mathrm{M}-\mathrm{H}-\mathrm{R}^{\prime}{ }_{3}, \mathrm{CH}=\mathrm{C}=\mathrm{O}-74-\right.\right.$ $\left.\left.\mathrm{R}_{2} \mathrm{CO}_{2} \mathrm{H}\right]^{-}\right)$. Compared to the 16:0/16:1-PG standard (Figure 5a) obtained under the same condition, the striking similarity in the profile of the $\mathrm{m} / \mathrm{z} 391$ and 389 ions suggests that the $\mathrm{m} / \mathrm{z} 927$ ion likely possesses a 16:0- and 16:1-acyl at $s n-1$ and $s n-2$, respectively. Since the ion series is the most prominent in the spectrum, the observation of the abundances of $\mathrm{m} / \mathrm{z} 391>\mathrm{m} / \mathrm{z} 361 \gg$ $\mathrm{m} / \mathrm{z} 389$ provides an unambiguous method with which 16:0-, 16:1-, and 14:1-fatty acyl substituents can be easily assigned at $s n-1, s n-2$ and $s n-3^{\prime}$, respectively.

The prominence of the $\mathrm{m} / \mathrm{z} 361$ ion may also suggest that the 14:1-acyl moiety resides at $s n-3^{\prime}$ rather than at $s n-2^{\prime}$ of the glycerol head group. Probably, the pathways for the ketene or acid loss at $s n-3^{\prime}$ are similar to those leading to the analogous loss at $s n-1$, and different from those accountable for the losses at $s n-2$.

\section{Structural Confirmation of Acylphosphatidylglycerols by $M S^{3}$ Ion-Trap Tandem Mass Spectrometry}

As described earlier, the acyl moiety at $s n-3^{\prime}$ is reflected by the presence of the ions at $\mathrm{m} / \mathrm{z} 719$ and 701 arising from losses of 14:1- ketene and of 14:1-acid, respectively. This is further confirmed by the $\mathrm{MS}^{3}$ spectrum of the $\mathrm{m} / \mathrm{z} 719$ ion (Figure $5 \mathrm{~b}$ ), arising from $\mathrm{m} / \mathrm{z}$ 927. The spectrum is nearly identical to the $\mathrm{MS}^{2}$ spectrum of 16:0/16:1-PG at $\mathrm{m} / \mathrm{z} 719$ (Figure 5a), indicating that probably a gaseous ion of $m / z 719$, similar to a $[\mathrm{M}-\mathrm{H}]^{-}$ ion of 16:0/16:1-PG, has been formed from $\mathrm{m} / \mathrm{z} 927$ by elimination of the 14:1-ketene at $s n-3^{\prime}$. In contrast, the MS $^{3}$ spectrum of the $\mathrm{m} / z 691$ ion (Figure $5 \mathrm{c}$ ), originated from a 16:1-ketene loss at $s n-2$ to become a $3^{\prime}$-myristoleoyl 1-palmitoyl 2-lyso phosphatidylglycerol (14:1-16: $0 /$ lyso2-PG), is dominated by ions at $\mathrm{m} / \mathrm{z} 465$ (691 $\left.\mathrm{C}_{13} \mathrm{H}_{25} \mathrm{CO}_{2} \mathrm{H}\right), 435\left(691-\mathrm{C}_{15} \mathrm{H}_{31} \mathrm{CO}_{2} \mathrm{H}\right), 391$ (465 - 74), and 361 (435-74), and can readily be differentiated from a product-ion spectrum of PG. The ion profile of the $\mathrm{MS}^{3}$ spectrum of the $\mathrm{m} / \mathrm{z} 689$ ion (data not shown), originated from a 16:0-ketene loss at $s n-1$ to a 14:1lyso1/16:1-PG ion, is also similar to that of a diacyl-PG. This result is consistent with the notion that the 14:1fatty acyl substituent resides at $s n-3^{\prime}$ rather than at $s n-2^{\prime}$ as described earlier.

The $\mathrm{MS}^{3}$ spectrum of the $\left[\mathrm{M}-\mathrm{H}-\mathrm{R}_{3^{\prime}} \mathrm{CO}_{2} \mathrm{H}\right]^{-}$ion of $\mathrm{m} / \mathrm{z} 701$ ion (Figure $5 \mathrm{~d}$ ) from a primary loss of 14:1-fatty acid from $\mathrm{m} / \mathrm{z} 927$ contains major ions involving further losses of the 16:1-ketene at $s n-2$ or the 16:0-ketene at $s n-1$. These fragmentation processes lead to $\mathrm{m} / \mathrm{z} 465$ (701 - $\left.\mathrm{C}_{14} \mathrm{H}_{27} \mathrm{CH}=\mathrm{CO}\right)$ and $391\left(701-\mathrm{C}_{14} \mathrm{H}_{27} \mathrm{CH}=\mathrm{CO}-74\right)$, involving loss of a 16:1-ketene moiety, and ions at 463 $\left(701-\mathrm{C}_{14} \mathrm{H}_{29} \mathrm{CH}=\mathrm{CO}\right)$ and $389\left(701-\mathrm{C}_{14} \mathrm{H}_{29} \mathrm{CH}=\mathrm{CO}-\right.$ 

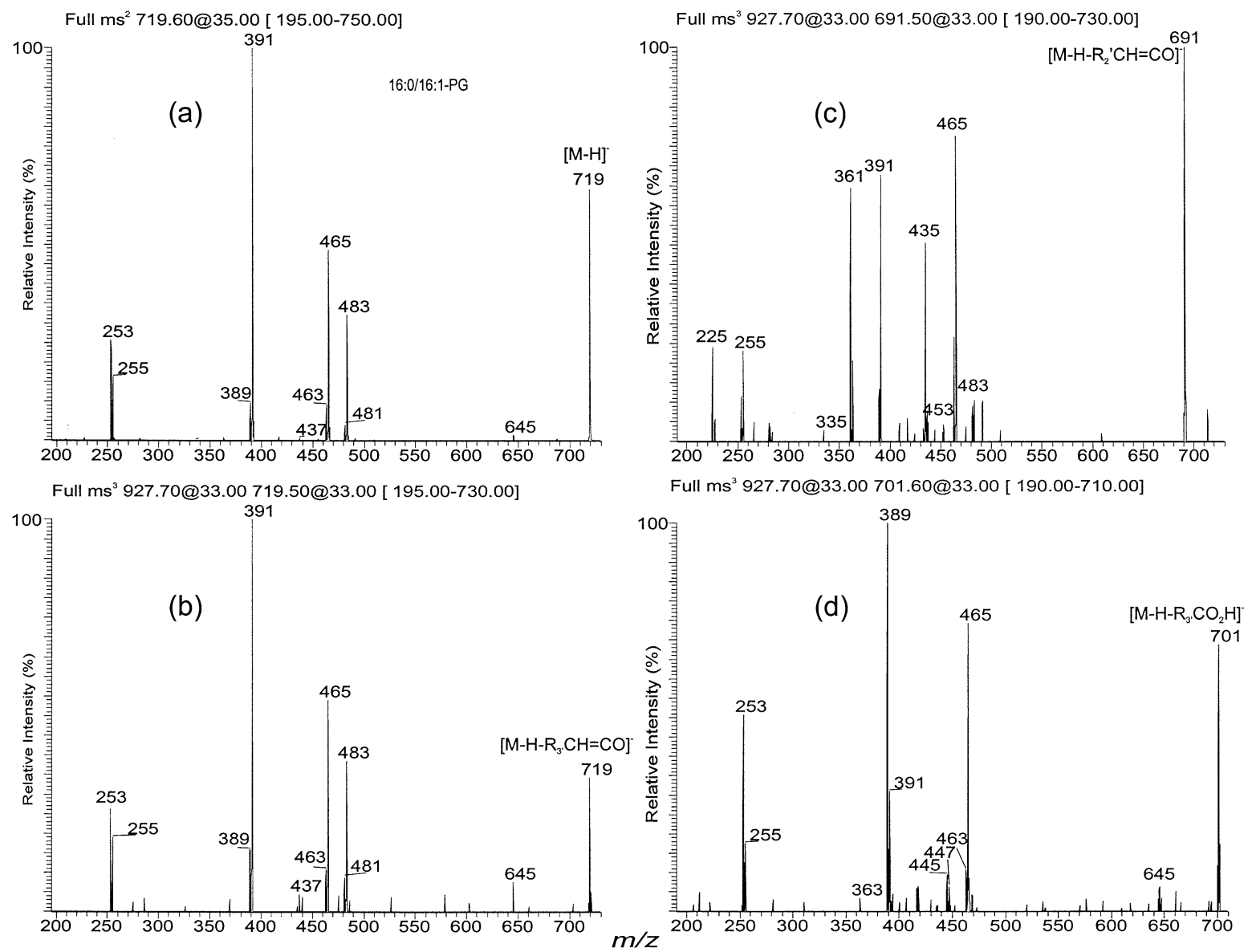

Figure 5. (a) The ITMS MS ${ }^{2}$ spectrum of 16:0/16:1-PG at $m / z$ 719. (b-d) The ITMS MS ${ }^{3}$ spectra of $m / z$ $719\left(\left[927-\mathrm{R}_{3^{\prime}} \mathrm{CH}=\mathrm{CO}\right]^{-}\right)(\mathbf{b}), m / z 691\left(\left[927-\mathrm{R}_{2}{ }_{2} \mathrm{CH}=\mathrm{CO}\right]^{-}\right)(\mathbf{c})$, and $m / z 701\left(\left[927-\mathrm{R}_{{ }^{\prime}}{ }^{\prime} \mathrm{CO}_{2} \mathrm{H}\right]^{-}\right)(\mathbf{d})$, from $\mathrm{MS}^{2}$ of $m / z 927$ (14:1-16:0/16:1-PG, Figure 4a).

74), involving a 16:0-ketene loss. The $m / z 465$ is more abundant than $\mathrm{m} / \mathrm{z} 463$, reaffirming that the 16:1-fatty acid is located at $s n-2$ of the glycerol backbone. The $\mathrm{m} / \mathrm{z}$ 465 and 463 ions are also more abundant than the $\mathrm{m} / \mathrm{z}$ $447\left(701-\mathrm{C}_{14} \mathrm{H}_{27} \mathrm{CO}_{2} \mathrm{H}\right)$ and $445\left(701-\mathrm{C}_{14} \mathrm{H}_{29} \mathrm{CO}_{2} \mathrm{H}\right)$, respectively. This is consistent with the idea that $\mathrm{m} / \mathrm{z}$ 701 ion resulting from an initial loss of acid from $\mathrm{m} / \mathrm{z}$ 927 becomes more basic (or less acidic) and undergoes preferential ketene than acid loss [14, 18, 19]. The ion profile of the $\mathrm{MS}^{3}$ spectrum of the $\left[\mathrm{M}-\mathrm{H}-\mathrm{R}_{1} \mathrm{CO}_{2} \mathrm{H}\right]^{-}$ ion of $\mathrm{m} / \mathrm{z} 671$ ion (data not shown) is similar to that arising from $\mathrm{m} / \mathrm{z} 701$ and is readily differentiable from that arising from the $\left[\mathrm{M}-\mathrm{H}-\mathrm{R}_{2} \mathrm{CO}_{2} \mathrm{H}\right]^{-}$ion of $m / z 673$ (data not shown). This is consistent with the idea that the pathways for the ketene or acid loss at $s n-3^{\prime}$ and $s n-1$ are similar but different from that at $s n-2$.

\section{Differentiation of Positional Isomers of Acyl-PG}

Positional isomers of acyl-PG were also observed in the extracts from inner and outer membranes (Table 1). As shown in Figure 6a, the product-ion spectrum of $\mathrm{m} / \mathrm{z}$ 983 in the extract isolated from inner membrane is dominated by the carboxylate anions at $m / z 281$ (18:1),
255 (16:0), and 253 (16:1). Since the $m / z 281$ ion is more abundant than $\mathrm{m} / \mathrm{z} 253$, which is much more abundant than $m / z 255$, the structure of the molecule can be easily assigned as 16:1-16:0/18:1-PG. This assignment is further supported by the observation of the abundances of $m / z 719\left(\left[\mathrm{M}-\mathrm{H}-\mathrm{C}_{16} \mathrm{H}_{31} \mathrm{CH}=\mathrm{CO}\right]^{-}\right)>m / z 701([\mathrm{M}-\mathrm{H}$ $\left.\left.-\mathrm{C}_{17} \mathrm{H}_{33} \mathrm{CO}_{2} \mathrm{H}\right]^{-}\right)$, signifying that the 18:1-acyl moiety resides at $s n-2$. The assignment is also consistent with the fact that the $m / z 719$ and 701 ion pairs are the most prominent among the ion series arising from acid or ketene loss. The $m / z 745\left(\left[\mathrm{M}-\mathrm{H}-\mathrm{C}_{14} \mathrm{H}_{29} \mathrm{CH}=\mathrm{CO}\right]^{-}\right)$ion is less abundant than $m / z 727\left(\left[\mathrm{M}-\mathrm{H}-\mathrm{C}_{15} \mathrm{H}_{31} \mathrm{CO}_{2} \mathrm{H}\right]^{-}\right)$ and the ion pairs are the least prominent in the series. The results suggest that the 16:0-acyl moiety positions at $s n-1$, whereas the 16:1-acyl is located at $s n-3^{\prime}$ and are in accord with the observation of the 16:1-acyl glycerophosphate anion at $\mathrm{m} / \mathrm{z} 407$.

The abundance of the $\mathrm{R}_{2} \mathrm{CO}_{2}^{-}$ion at $m / z 253$ appears to be higher than that expected for a 16:1-16:0/18:1-PG, attributable to the fact that a minor 16:0-18:1/16:1-PG isomer is also present. This assumption is based on the findings that the $\mathrm{m} / \mathrm{z} 747\left(\left[\mathrm{M}-\mathrm{H}-\mathrm{C}_{14} \mathrm{H}_{27} \mathrm{CH}=\mathrm{CO}\right]^{-}\right)$ ion is slightly more abundant than $\mathrm{m} / \mathrm{z} 729$ ([M - H $\left.\mathrm{C}_{15} \mathrm{H}_{29} \mathrm{CO}_{2} \mathrm{H}\right]^{-}$), indicating the presence of a 16:1-acyl at 

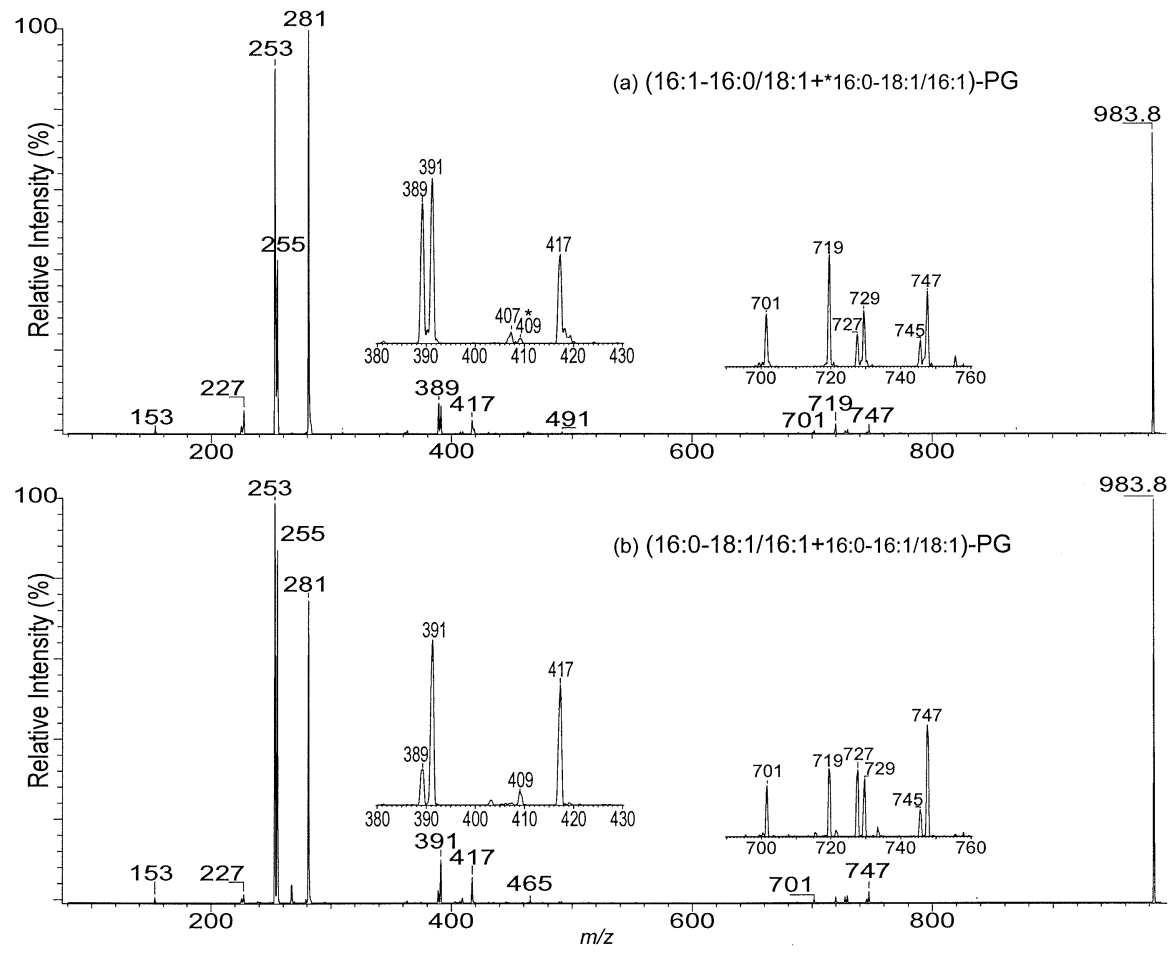

Figure 6. The tandem quadrupole product-ion spectra of the $m / z 983$ ions isolated from (a) inner membrane, and (b) outer membrane. The profiles of the two spectra are different substantially, indicating that they are positional isomers. The two compounds also contain minor positional isomers, which are marked with an asterisk.

$s n-2$. The structural assignment of this latter isomer is further confirmed by the observation of the 16:0-acyl glycerophosphate ion at $m / z$ 409, which signifies a 16:0-acyl at $s n-3^{\prime}$. The abundance of $m / z 417$ ion is also higher than that anticipated for a 16:1-16:0/18:1-PG and consistent with the notion of the presence of a second 16:0-18:1/16:1-PG isomer that results in the rise of the $m / z 417$ ion.

The abundance of $m / z 253$ ion is greater than that of $m / z 255$, which is more abundant than $m / z 281$ in the product-ion spectrum of $m / z 983$ arising from the extract of outer membrane (Figure $6 b$ ). Hence the species can be easily identified as 16:0-18:1/16:1-PG. The assignment is further supported by the observation of $\mathrm{m} / \mathrm{z}$ $747\left(\left[\mathrm{M}-\mathrm{H}-\mathrm{C}_{14} \mathrm{H}_{27} \mathrm{CH}=\mathrm{CO}\right]^{-}\right)>m / z 729([\mathrm{M}-\mathrm{H}-$ $\left.\left.\mathrm{C}_{15} \mathrm{H}_{29} \mathrm{CO}_{2} \mathrm{H}\right]^{-}\right)$, confirming a 16:1-acyl at sn-2, along with the presence of $m / z \quad 745([\mathrm{M}-\mathrm{H}$ $\left.\left.\mathrm{C}_{14} \mathrm{H}_{29} \mathrm{CH}=\mathrm{CO}\right]^{-}\right)<m / z 727\left(\left[\mathrm{M}-\mathrm{H}-\mathrm{C}_{15} \mathrm{H}_{31} \mathrm{CO}_{2} \mathrm{H}\right]^{-}\right)$, signifying the existence of a 16:0-acyl at $s n-3^{\prime}$ or $s n-1$. The assignment of the 16:0-acyl at $s n-3^{\prime}$ is determined by the presence of $m / z 391$ together with $m / z 409$, a 16:0-acyl glycerophosphate ion that involves the $s n-3^{\prime}$ fatty acyl substituent.

The abundances of the $m / z 255$ and 281 ions are higher than those predicted for a $16: 0-18: 1 / 16: 1-P G$, suggesting the presence of an additional isomer. This is also based on the findings that the abundance of $m / z 719$ $\left(\left[\mathrm{M}-\mathrm{H}-\mathrm{C}_{16} \mathrm{H}_{31} \mathrm{CH}=\mathrm{CO}\right]^{-}\right)$is slightly greater than $\mathrm{m} / \mathrm{z}$ $701\left(\left[\mathrm{M}-\mathrm{H}-\mathrm{C}_{17} \mathrm{H}_{33} \mathrm{CO}_{2} \mathrm{H}\right]^{-}\right)$, indicating the presence of a 18:1-acyl at $s n$-2. The 16:0-acyl glycerophosphate at $m / z 409$ that signifies a 16:0-acyl at $s n-3^{\prime}$ is the exclusive ion of the ion series in the spectrum, indicating that both the isomers possess a 16:0-acyl at $s n-3^{\prime}$. Therefore, the minor isomer with a structure of 16:0-16:1/18:1-PG can be deduced.

\section{Structural Characterization of the Molecular Species Containing Two Identical Fatty Acyl Moieties}

Although the observation of abundances of $\mathrm{R}_{2} \mathrm{CO}_{2}^{-}>$ $\mathrm{R}_{3}, \mathrm{CO}_{2}^{-} \gg \mathrm{R}_{1} \mathrm{CO}_{2}^{-}$provides a simple method leading to the assignment of the structure of an acyl-PG, this strategy is not applicable for molecules having two identical fatty acyl substituents at two different positions, or comprising more than one isomeric structures. This is attributable to the fact that the abundances of the carboxylate anions are complicated by the contribution of the identical fatty acyl groups at different positions or by the contribution of the fatty acyl groups from various isomers. For example, the product-ion spectrum of the $[\mathrm{M}-\mathrm{H}]^{-}$ion at $m / z 1009$ (Figure 7a) contains $\mathrm{R}_{\mathrm{x}} \mathrm{CO}_{2}^{-}$ions at $m / z 253$ and 281, indicating the presence of both 16:1- and 18:1-fatty acyl moieties, but their position in the molecule based on their abundances is not applicable. However, the identity of the 18:1-fatty acyl substituent at sn-2 can be easily recognized by the observation of the greater abundance of the $m / z 745$ ion, arising from loss of 18:1-ketene, than 

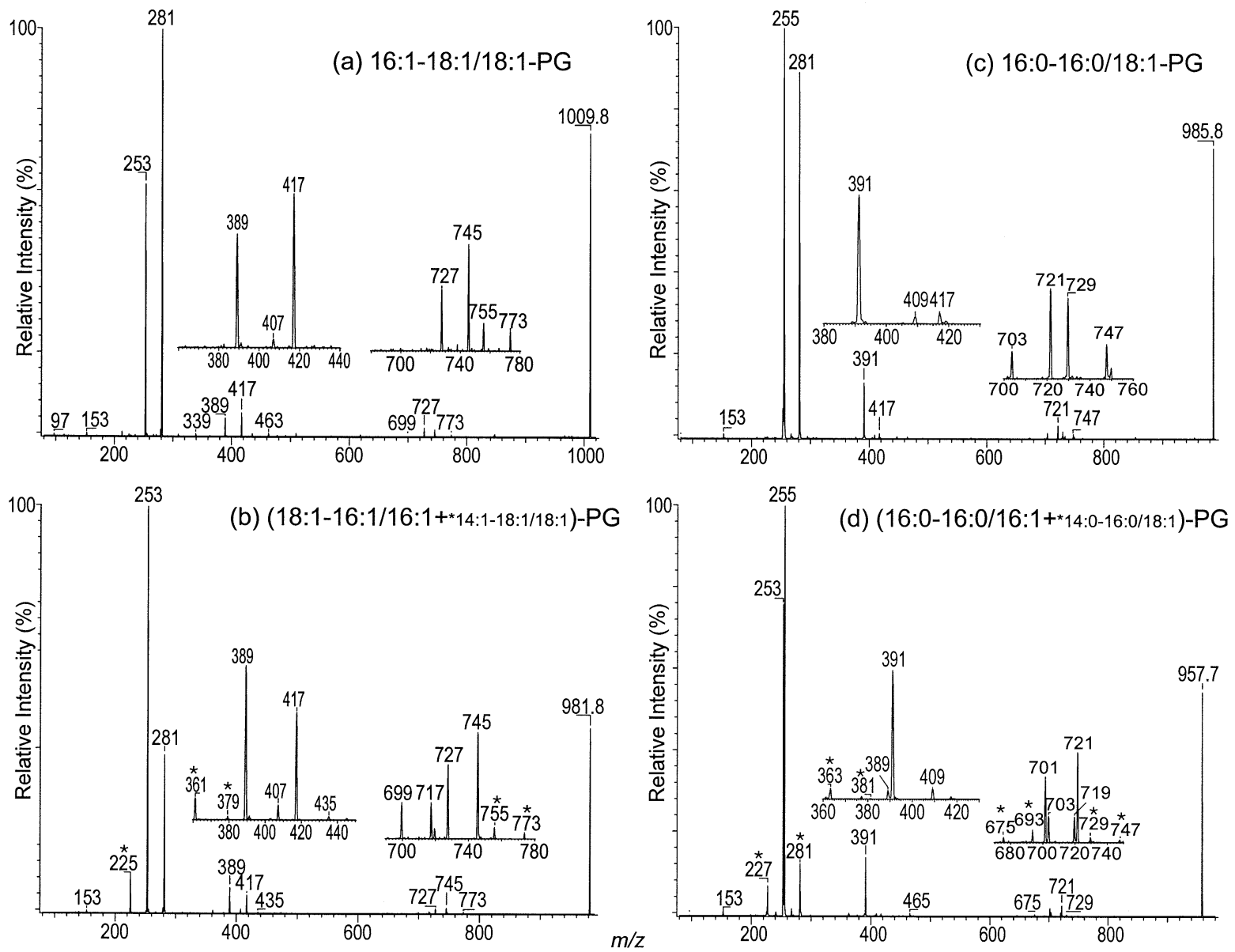

Figure 7. The tandem quadrupole product-ion spectra of $[\mathrm{M}-\mathrm{H}]^{-}$ions of (a) $\mathrm{m} / \mathrm{z} 1009,(\mathbf{b}) \mathrm{m} / \mathrm{z}$ 981, (c) $\mathrm{m} / \mathrm{z}$ 985, and (d) $\mathrm{m} / \mathrm{z}$ 957. The structural characterizations are complicated by the presence of two identical fatty acyl substituents in the molecules however, the identifications can be achieved by the combined information arising from the various ion series.

$m / z 727$, arising from loss of 18:1-acid. The $m / z 773$ ion arising from loss of 16:1-ketene is less abundant than $\mathrm{m} / \mathrm{z} 755$, arising from loss of 16:1-acid. This information leads to the assignment of the 16:1-acyl residing at either $s n-1$ or $s n-3^{\prime}$. A 16:1-acyl glycerophosphate anion at $m / z 407$ along with $m / z 389$, rather than a 18:1-acyl glycerophosphate anion at $\mathrm{m} / \mathrm{z} 453$, is also observed in the spectrum. This confirms the assignment of 16:1-fatty acyl at $s n-3^{\prime}$, whereas the remaining 18:1-fatty acyl is located at $s n-2$.

Similar results were also observed for the $[\mathrm{M}-\mathrm{H}]^{-}$ ion at $m / z 981$ (Figure $7 b$ ), which comprises a 18:1-16: 1/16:1-PG structure, along with a minor 14:1-18:1/18: 1-PG isomer. The structure of 14:1-18:1/18:1-PG is identified by the observation of the abundances of $\mathrm{m} / \mathrm{z} 773<$ $\mathrm{m} / \mathrm{z} 755$, arising from a respective 14:1-ketene and 14:1-acid loss, along with ions at $m / z 361$ and 379 that signify the presence of a 14:1-acyl residing at $s n-3^{\prime}$. The presence of 14:1-acyl is also consistent with the observation of a carboxylate anion at $\mathrm{m} / \mathrm{z} 225$.

Structural identification of acyl-PGs with identical fatty acyl substituens at $s n-1$ and $s n-3^{\prime}(\mathrm{a}-\mathrm{b} / \mathrm{c}$, where $\mathrm{a}=$ b) is exemplified by the product-ion spectrum of the $[\mathrm{M}$
- $\mathrm{H}]^{-}$ion at $\mathrm{m} / \mathrm{z} 985$ (Figure 7c), which contains carboxylate anions at $\mathrm{m} / \mathrm{z} 255$ and 281, reflecting the 16:0- and 18:1-acyl constituents. The structural identification is achieved by the observation of the greater abundance of $m / z 721\left(\left[\mathrm{M}-\mathrm{H}-\mathrm{C}_{16} \mathrm{H}_{31} \mathrm{CH}=\mathrm{CO}\right]^{-}\right)$than $m / z 703\left(\left[\mathrm{M}-\mathrm{H}-\mathrm{C}_{17} \mathrm{H}_{33} \mathrm{CO}_{2} \mathrm{H}\right]^{-}\right)$, signifying a 18:1acyl residing at $s n-2$, along with the observation of the preferential formation of $\mathrm{m} / \mathrm{z} 729$ ([M - H $\left.\left.\mathrm{C}_{15} \mathrm{H}_{31} \mathrm{CO}_{2} \mathrm{H}\right]^{-}\right)$over $\mathrm{m} / \mathrm{z} \quad 747 \quad([\mathrm{M}-\mathrm{H}$ $\left.\mathrm{C}_{14} \mathrm{H}_{29} \mathrm{CH}=\mathrm{CO}\right]^{-}$), signifying the presence of a 16:0-fatty acyl at $s n-1$ and/or $s n-3^{\prime}$. Since a prominent ion at $m / z$ 391 together with $m / z 409$ is also present in the spectrum, the assignment of 16:0-acyl at $s n-3^{\prime}$ can be easily confirmed.

The product-ion spectrum of $\mathrm{m} / \mathrm{z} 957$ (Figure 6d) contains a similar ion profile, which leads to identification of a 16:0-16:0/16:1-PG structure. However, carboxylate anions at $\mathrm{m} / \mathrm{z} 281$ and 227 were also observed in the spectrum, suggesting that another isomer comprising a 18:1- and/or 14:1-acyl moiety may also exist. This is further revealed by observation of the greater abundance of the $\mathrm{m} / \mathrm{z} 693\left(\left[\mathrm{M}-\mathrm{H}-\mathrm{C}_{16} \mathrm{H}_{31} \mathrm{CH}=\mathrm{CO}\right]^{-}\right)$ion than $m / z 675\left(\left[\mathrm{M}-\mathrm{H}-\mathrm{C}_{17} \mathrm{H}_{33} \mathrm{CO}_{2} \mathrm{H}\right]^{-}\right)$, which arise 

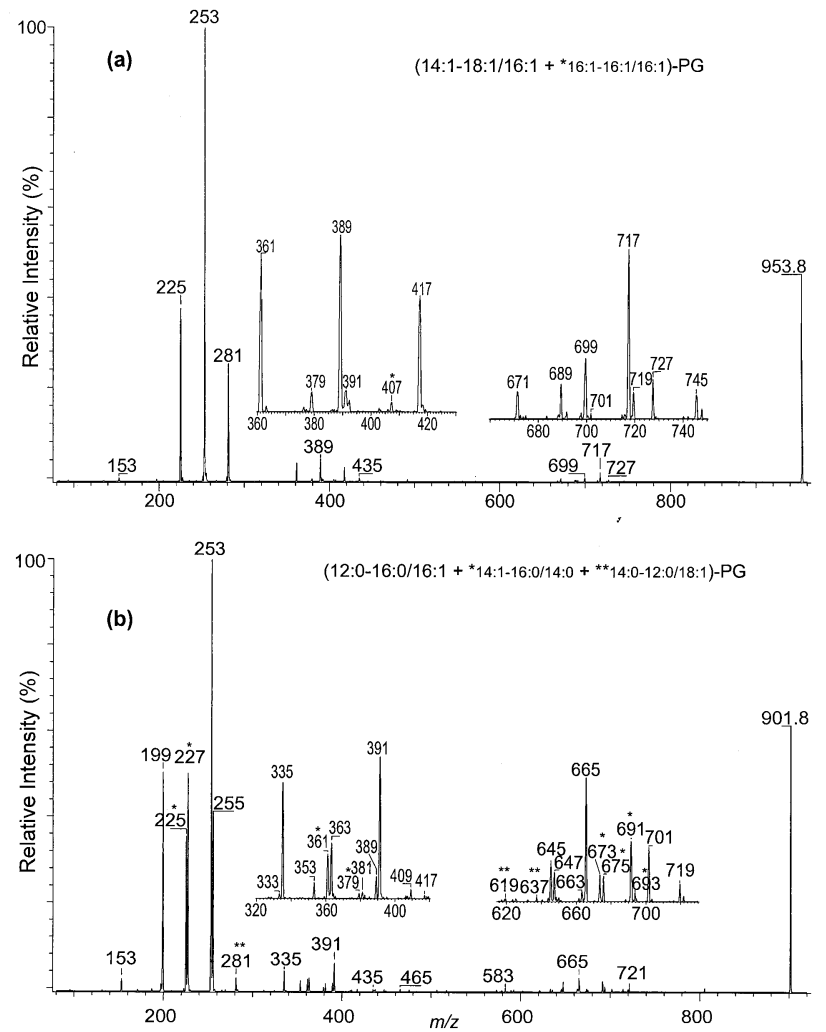

Figure 8. The tandem quadrupole product-ion spectra of the [M $-\mathrm{H}]^{-}$ions of (a) $\mathrm{m} / \mathrm{z}$ 953, and (b) $\mathrm{m} / \mathrm{z}$ 901. The molecular species consist of two $(\mathrm{m} / \mathrm{z}$ 953, Panel a) and three $(\mathrm{m} / \mathrm{z}$ 901, Panel b) configuration isomers, respectively.

from losses of 18:1-acyl moiety residing at $s n-2$ as a ketene and acid, respectively. The spectrum also contains ions at $m / z 747\left(\left[\mathrm{M}-\mathrm{H}-\mathrm{C}_{12} \mathrm{H}_{25} \mathrm{CH}=\mathrm{CO}\right]^{-}\right)$, which is less abundant than $m / z \quad 729$ ([M - $\mathrm{H}-$ $\left.\mathrm{C}_{13} \mathrm{H}_{27} \mathrm{CO}_{2} \mathrm{H}\right]^{-}$), indicating the presence of a $14: 0$ at $s n-1$ or $s n-3^{\prime}$. The 14:0-acyl at $s n-3^{\prime}$ is confirmed by the presence of the ions at $m / z 363$ and 381. Therefore, a minor isomer with a 14:0-16:0/18:1-PG structure can be determined.

\section{Structural Determination of Acyl-PG Molecular Species with Multiple Isobaric Isomers}

As shown in Figure 8a, the product-ion spectrum of $m / z$ 953 is dominated by the $\mathrm{R}_{\mathrm{x}} \mathrm{CO}_{2}^{-}$ions at $m / z 281$ (18:1), 253 (16:1), and 225 (14:1). Because the abundances of the ions are in the order: $m / z 253>m / z 225>m / z 281$, the structure can be easily assigned as 14:1-18:1/16:1-PG. This configuration is consistent with the observation of the abundances of $m / z 717\left(\left[\mathrm{M}-\mathrm{H}-\mathrm{C}_{14} \mathrm{H}_{29} \mathrm{CH}=\mathrm{CO}\right]^{-}\right)$ $>m / z 699\left(\left[\mathrm{M}-\mathrm{H}-\mathrm{C}_{15} \mathrm{H}_{31} \mathrm{CO}_{2} \mathrm{H}\right]^{-}\right) ; m / z 745([\mathrm{M}-\mathrm{H}$ - $\left.\left.\mathrm{C}_{12} \mathrm{H}_{23} \mathrm{CH}=\mathrm{CO}\right]^{-}\right)<m / z 727([\mathrm{M}-\mathrm{H}$ $\left.\left.\mathrm{C}_{13} \mathrm{H}_{25} \mathrm{CO}_{2} \mathrm{H}\right]^{-}\right) ; m / z 689\left(\left[\mathrm{M}-\mathrm{H}-\mathrm{C}_{16} \mathrm{H}_{31} \mathrm{CH}=\mathrm{CO}\right]^{-}\right) \leq$ $m / z 671\left(\left[\mathrm{M}-\mathrm{H}-\mathrm{C}_{17} \mathrm{H}_{33} \mathrm{CO}_{2} \mathrm{H}\right]^{-}\right)$. However, the abundance of $\mathrm{R}_{2} \mathrm{CO}_{2}^{-}$ion at $m / z 253$ is higher than that predicted for 14:1-18:1/16:1-PG that consists of various acyl moieties. A 16:1-acyl glycerophosphate ion at $\mathrm{m} / \mathrm{z}$
407 that signifies a $16: 1$-acyl at $s n-3^{\prime}$ is also observed in the spectrum, suggesting the presence of a 16:1-16:1/ 16:1-PG isomer. This is further evidenced by the rise of the $m / z 717$ and 699 ions, which are higher than the abundances anticipated from a 14:1-18:1/16:1-PG, along with a prominent $m / z 389$ ion, which arises from the $16: 1-16: 1 / 16: 1-P G$ isomer.

Several isomers were identified for the ions at $\mathrm{m} / \mathrm{z}$ 901, 955 and 971 (Table 1). The complexities of the structures of the molecules are demonstrated by the product-ion spectrum of $\mathrm{m} / \mathrm{z} 901$ (Figure $8 \mathrm{~b}$ ), which contains $\mathrm{R}_{\mathrm{x}} \mathrm{CO}_{2}^{-}$ions at $m / z 281$ (18:1), 255 (16:0), 253 (16:1), 227 (14:0), 225 (14:1), and 199 (12:0). Three sets of ions featured by abundances of $\left[\mathrm{M}-\mathrm{H}-\mathrm{R}^{\prime}{ }_{\mathrm{x}} \mathrm{CH}=\mathrm{CO}\right]^{-}$ $>\left[\mathrm{M}-\mathrm{H}-\mathrm{R}_{\mathrm{x}} \mathrm{CO}_{2} \mathrm{H}\right]^{-}$, that reflects the acyl substituents at $s n-2$ position were observed at: $m / z 665([\mathrm{M}-\mathrm{H}$ - $\left.\left.\mathrm{C}_{14} \mathrm{H}_{27} \mathrm{CH}=\mathrm{CO}\right]^{-}\right)>m / z \quad 647([\mathrm{M}-\mathrm{H}$ $\left.\left.\mathrm{C}_{15} \mathrm{H}_{29} \mathrm{CO}_{2} \mathrm{H}\right]^{-}\right) ; m / z$ 691( $\left.\left[\mathrm{M}-\mathrm{H}-\mathrm{C}_{12} \mathrm{H}_{25} \mathrm{CH}=\mathrm{CO}\right]^{-}\right)>$ $m / z 673\left(\left[\mathrm{M}-\mathrm{H}-\mathrm{C}_{13} \mathrm{H}_{27} \mathrm{CO}_{2} \mathrm{H}\right]^{-}\right)$; and $m / z 637([\mathrm{M}-$ $\left.\left.\mathrm{H}-\mathrm{C}_{16} \mathrm{H}_{31} \mathrm{CH}=\mathrm{CO}\right]^{-}\right)>m / z \quad 619$ ([M - $\mathrm{H}$ $\left.\mathrm{C}_{17} \mathrm{H}_{33} \mathrm{CO}_{2} \mathrm{H}\right]^{-}$). These results suggest that the $[\mathrm{M}-$ $\mathrm{H}]^{-}$ion of $m / z 901$ represents three isomeric structures possessing 16:1-, 14:0-, and 18:1-acyl substituents at the sn-2 position, respectively. The acyl-PG with a 16:1-acyl at $s n-2$ is the major species, because the $m / z 665$ and 647 ion pairs are the most prominent in the series. The ion-pairs with abundances of $\left[\mathrm{M}-\mathrm{H}-\mathrm{R}_{\mathrm{x}} \mathrm{CH}_{\mathrm{C}} \mathrm{CO}\right]^{-}<$ $\left[\mathrm{M}-\mathrm{H}-\mathrm{R}_{\mathrm{x}} \mathrm{CO}_{2} \mathrm{H}\right]^{-}$were observed at: $m / z 719([\mathrm{M}-\mathrm{H}$ - $\left.\left.\mathrm{C}_{10} \mathrm{H}_{21} \mathrm{CH}=\mathrm{CO}\right]^{-}\right)<m / z 701([\mathrm{M}-\mathrm{H}$ $\left.\left.\mathrm{C}_{11} \mathrm{H}_{23} \mathrm{CO}_{2} \mathrm{H}\right]^{-}\right) ; m / z 663\left(\left[\mathrm{M}-\mathrm{H}-\mathrm{C}_{14} \mathrm{H}_{29} \mathrm{CH}=\mathrm{CO}\right]^{-}\right)<$ $m / z 645\left(\left[\mathrm{M}-\mathrm{H}-\mathrm{C}_{15} \mathrm{H}_{31} \mathrm{CO}_{2} \mathrm{H}\right]^{-}\right) ; m / z 693([\mathrm{M}-\mathrm{H}-$ $\left.\left.\mathrm{C}_{12} \mathrm{H}_{23} \mathrm{CH}=\mathrm{CO}\right]^{-}\right)<m / z 675\left(\left[\mathrm{M}-\mathrm{H}-\mathrm{C}_{13} \mathrm{H}_{25} \mathrm{CO}_{2} \mathrm{H}\right]^{-}\right)$. These results lead to identify the fatty acyl moieties of 12:0-, 16:0-, and 14:1 at $s n-1$ or $s n-3^{\prime}$. The ion set of $m / z$ 719 and 701 is the most prominent among the ion series, indicating that probably an acyl-PG possessing a 16:1acyl at $s n-2$, a 12:0-acyl moiety at $s n-1$ or $s n-3^{\prime}$, together with a 16:0-acyl is the major species. The determination of the fatty acyl substituent at $s n-3^{\prime}$ is achieved by observation of the acyl glycerophosphate ions at $\mathrm{m} / \mathrm{z}$ 353,379 , and 381, reflecting a 12:0-, 14:1-, and 14:0-acyl moieties, respectively. Therefore, the major species with a 12:0-16:0/16:1-PG structure can be determined. The identification of the two minor species with a respective 14:0- and 18:1-acyl at sn-2, along with a 14:1- or 14:0-acyl group at $s n-3^{\prime}$ are described below.

The sum of the number of the unsaturated bonds of the fatty acyl substituents in the molecule is one, as observed for the major 12:0-16:0/16:1-PG species. Hence, the species with a 18:1-acyl at sn-2 most likely contains a 14:0-acyl at $s n-3^{\prime}$ to constitute a 14:0-12:0/18: 1-PG, while the species with a 14:0-acyl at sn-2 may be a 14:1-16:0/14:0-PG. This assumption is also based on the findings that the $14: 0-12: 0 / 18: 1-P G$ is the least prominent, as observed by the abundance of the carboxylate anion at $m / z 281$, and the abundances of the ions at $m / z 637$ and 619 . In contrast, carboxylate anions at $m / z 225$ and 227, ions at $m / z 361,363$, and 379, along with the ion sets of $m / z 693$ and $m / z 675$, and of $m / z 691$ 
and $\mathrm{m} / \mathrm{z} 673$ are all in moderate abundance and are likely arising from the 14:1-16:0/14:0-PG.

\section{Conclusions}

Product-ion spectra of acyl-PG obtained with TSQ or ITMS contain rich structural information, with which structural characterization can be achieved. The product-ion spectra acquired by TSQ are dominated by carboxylate anions, whereas structurally informative fragment ions observed by ITMS are more evenly distributed. The mass spectrometric methods are applicable to acyl-PG mixtures, and structural details, including the identities and the positions of the fatty acyl substituents, can be determined. In contrast, determination of the structure of acyl-PG as described by Holmback et al. [11] required several analytical methods including NMR, LC/MS/MS, and GC/MS and structural information such as the positions of the fatty acyl moieties of complex molecules are not available. Characterization of acyl-PG molecules of biological origins is complicated by the presence of various isomers, including configuration and positional isomers. However, a complete structural elucidation can be achieved by the fragment ion information arising from the various ion series as described in this study.

\section{Acknowledgments}

This research was supported by U.S. Public Health Service grants P41-RR-00954，R37-DK-34388，P60-DK-20579，P30-DK56341 and P01-HL-57-278 and a grant (996003) from the Juvenile Diabetes Foundation.

\section{References}

1. Plackett, P.; Smith, P. F.; Mayberry, W. R. Lipids of a SterolNonrequiring Mycoplasma. J. Bacteriol 1970, 104, 798-807.

2. Olsen, R. W.; Ballou, C. E. Acyl Phosphatidylglycerol. A New Phospholipid from Salmonella typhimurium.. J. Biol. Chem. 1971, 246, 3305-3313.

3. Makula, R. A.; Torregrossa, R. E.; Isle, H. B. Identification and Synthesis of Acyl-Phosphatidylglycerol in Acinetobacter sp. HO1-N. J. Bacteriol. 1978, 133, 1530-1532.

4. Cho, K. S.; Hong, S. D.; Cho, J. M.; Chang, C. S.; Lee, K. S. Studies on the Biosynthesis of Acylphosphatidylglycerol in Escherichia coli B and B/r. Biochim. Biophys. Acta 1976, 486, 47 -54 .

5. Homma, H.; Nojima, S. Synthesis of Various Phospholipids from 2-Acyl Lysophospholipids by Escherichia coli extract. J. Biochem. (Tokyo) 1982, 91, 1103-1110.
6. Ellingson, J. S. Identification of N-Acylethanolamine Phosphoglycerides and Acylphosphatidylglycerol as the Phospholipids which Disappear as Dictyostelium discoideum Cells Aggregate. Biochemistry 1980, 19, 6176-6182.

7. Beach, D. H.; Holz, G. G., Jr; Singh, B. N.; Lindmark, D. G. Phospholipid Metabolism of Cultured Trichomonas vaginalis and Trichomonas foetus.. Mol. Biochem. Parasitol. 1991, 44, 97108.

8. Huterer, S. J.; Wherrett, J. R. Formation of Acylphosphatidylglycerol by a Lysosomal Phosphatidylcholine: Bis(Monoacylglycero)Phosphate Acyl Transferase. Biochem. Cell Biol. 1990, 68, 366-372.

9. Poorthuis, B. J. H. M.; Hostetler, K. Y. Biosynthesis of Bis(Monoacylglyceryl)Phosphate and Acylphosphatidylglycerol in Rat Liver Mitochondrial Preparations. J. Biol. Chem. 1975, 250, 3297-3302.

10. Waite, M.; King, L.; Thornburg, T.; Osthoff, G.; Thuren, T. Y. Metabolism of Phosphatidylglycerol and Bis(Monoacylglycero)-Phosphate in Macrophage Subcellular Fractions. J. Biol. Chem. 1990, 265, 21720-21726.

11. Holmback, J.; Karlsson, A. A.; Arnoldsson, K. C. Characterization of N-Acylphosphatidylethanolamine and Acylphosphatidylglycerol in Oats. Lipids 2001, 36, 153-165.

12. Niepel, T.; Meyer, H.; Wray, V.; Abraham, W. R. Intraspecific Variation of Unusual Phospholipids from Corynebacterium spp. Containing a Novel Fatty Acid. J. Bacteriol. 1998, 180, 4650-4657.

13. Costello, C. E.; Beach, D. H.; Singh, B. N. Acidic Glycerol Lipids of Trichomonas vaginalis and Tritrichomonas foetus.. Biol. Chem. 2001, 382, 275-281.

14. Hsu, F. F.; Turk, J. Studies on Phosphatidylglycerol with Triple Quadrupole Tandem Mass Spectrometry with Electrospray Ionization: Fragmentation Processes and Structural Characterization. J. Am. Soc. Mass Spectrom. 2001, 12, $1036-$ 1043.

15. Snavely, M. D.; Miller, C. G.; Maguire, M. E. The mgtB Mg2+ Transport Locus of Salmonella typhimurium encodes a P-Type ATPase. J. Biol. Chem. 1991, 266(815), 823.

16. Yamato, I.; Anraku, Y.; Hirosawa, K. Cytoplasmic Membrane Vesicles of Escherichia coli. A Simple Method for Preparing the Cytoplasmic and Outer Membranes. J. Biochem. (Tokyo) 1975, 77, 705-718.

17. Bligh, E. G.; Dyer, W. J. A Rapid Method of Total Lipid Extraction and Purification. Can. J. Biochem. Physiol. 1959, 37, 911-917.

18. Hsu, F. F.; Turk, J. Charge-Driven Fragmentation Processes in Diacyl Glycerophosphatidic Acids Upon Low-Energy Collisional Activation. A Mechanistic Proposal. J. Am. Soc. Mass Spectrom. 2000, 11, 797-803.

19. Hsu, F. F.; Turk, J. Charge-Driven and Charge-Remote Fragmentation Processes in Diacyl Glycerophosphoethanolamine Upon Low-Energy Collisional Activation. A Mechanistic Proposal. J. Am. Soc. Mass Spectrom. 2000, 11, 892-899. 